\title{
Notes to tables
}

\section{Time series}

For most tables, years start at 1971 and then continue at five-year intervals until 1991. Individual years are shown thereafter.

\section{United Kingdom}

The United Kingdom comprises England, Wales, Scotland and Northern Ireland. The Channel Islands and the Isle of Man are not part of the United Kingdom.

\section{Population}

The estimated and projected resident population of an area includes all people who usually live there, whatever their nationality. Members of HM and US Armed Forces in the United Kingdom are included on a residential basis wherever possible. HM Forces stationed outside the United Kingdom are not included. Students are taken to be resident at their term time addresses.

Further information on population estimates is available on the National Statistics website at: www. statistics.gov.uk/popest

\section{Live birth}

For England and Wales, figures relate to the number of births occurring in a period; for Scotland and Norther Ireland, figures relate to births registered in a period. By law, births must be registered within 42 days in England and Wales, within 21 days in Scotland, and within 42 days in Northern Ireland. In England and Wales, where a birth is registered later than the legal time period, and too late to be included in the count for the year of occurrence, it will be included in the count for the following year.

Age specific fertility rate (ASFR), is the number of births per 1,000 women in the stated age group

The total fertility rate (TFR), which is the sum of the age-specific fertility rates expressed per woman, is a useful summary measure in that it can be used to examine both changes in fertility over time and between populations by removing the effect of different age distributions

Care should be taken in interpreting the total fertility rate as indicative of future levels of childbearing. Used in this way it may be interpreted as the number of children that would be born to a woman if the current age-specific patterns of fertility persisted throughout her childbearing life. However, the TFR is a synthetic measure since age-specific fertility rates do not normally remain stable during the childbearing life span of a woman.

\section{Perinatal mortality}

In October 1992 the legal definition of a stillbirth was changed, from baby born dead after 28 completed weeks of gestation or more, to one born dead after 24 completed weeks of gestation or more.

\section{Period expectation of life}

The life tables on which these expectations are based use death rates for the given period to describe mortality levels for each year. Each individual year shown is based on a three-year period, so that for instance 1986 represents 1985-87. More details can be found at www.statistics.gov.uk/StatBase/Product. asp? vlnk $=14459$

\section{Deaths}

Figures for England and Wales relate to the number of deaths registered in each year up until 1992, and the number of deaths occurring in a year between 1993 and 2005. From 2006 onwards, all figures relate to the number of deaths registered in the year. All figures for Scotland and Northern Ireland relate to the number of deaths registered in each year.

\section{Age-standardised mortality}

Directly age-standardised rates make allowances for changes in the age structure of the population. The age-standardised rate for a particular condition is that which would have occurred if the observed agespecific rates for the condition had applied in a given standard population. Table 2.2 uses the European Standard Population. This is a hypothetical population standard which is the same for both males and females allowing standardised rates to be compared for each sex, and between males and females.

\section{International Migratio}

The UN recommends the following definition of an international long-term migrant:

An international long-term migrant is defined as a person who moves to a country other than that of his or her usual residence for a period of at least a year (12 months), so that the country of destination effectively becomes his or her new country of usual residence.

Figures in Tables 7.1-7.3 are compiled from several main sources of migration data:

- The richest source of information on international migrants comes from the International Passenger Survey (IPS), which is a sample survey of passengers arriving at, and departing from, the main United Kingdom air and sea ports and Channel Tunnel. This survey provides migration estimates based on respondents' intended length of stay in the UK or abroad and excludes most of stay in the UK or abroad and excludes most
persons seeking asylum and some dependants of such asylum seekers.

- Two adjustments are made to account for people who do not realise their intended length of stay on arrival. First, visitor data from the IPS are used to estimate 'visitor switchers': those people who initially come to or leave the UK for a short period but subsequently stay for a year or longer. (For years before 2001, estimates of nonEuropean Economic Area (non-EEA) national visitor switcher inflows are made from the Home Office database of after-entry applications to remain in the UK). Second, people who intend to be migrants, but who in reality stay in the UK or abroad for less than a year ('migrant switchers'), are estimated from IPS migrant data.

- Home Office data on asylum seekers and their dependants.

- Estimates of migration between the UK and the Irish Republic estimated using information from the Irish Quarterly National Household Survey and the National Health Service Central Register, agreed between the Irish Central Statistics Office and the ONS.

Estimates for 1999-2005 have been revised to take account of recent improvements in the methodology used to estimate migration. These improvements were first published for 2006 data released in November first published for 2006 data released in November
2007. More detail is provided in Appendix B of International Migration 2006 - MN Series no. 33. For years prior to 1991, the figures in Tables 7.1-7.3 are based only on data from the IPS. After taking into account of those groups of migrants known not to be covered by the IPS, it is estimated that the adjustment needed to net migration ranges from about ten thousand in 1981 to just over twenty thousand in 1986 . From 1991, the figures in Tables 7.1-7.3 are based on data from all the sources and represent Total International Migration.

Old Commonwealth is defined as Australia, Canada, New Zealand and South Africa;

New Commonwealth is defined as all other Commonwealth countries.

Middle East is defined as Bahrain, Iran, Iraq, Israel, Jordan, Kuwait, Lebanon, Oman, Qatar, Saudi Arabia, Syria, the United Arab Emirates, and Yemen.

\section{Internal Migration}

Figures in Table 8.1 are based on the movement of NHS doctors' patients between former Health Authorities (HAs) in England and Wales, and Area Health Boards in Scotland and Northern Ireland. Yearly and quarterly figures have been adjusted to take account of differences in recorded cross-border flows between England and Wales, Scotland and Northern Ireland.

Prior to reorganisation of health authority databases from Family Health Service Authorities (FHSAs) to HAs some database boundaries were realigned. This included in a few cases transferring patients between databases to fit the new boundaries. For the most part, this movement was done outside the NHSCR system and therefore had no effect on migration data.
However a small number were transferred within the system. As migration estimates derived from NHSCR are the product of an administrative system (when patients re-register with GPs) this had the effect of generating small numbers of spurious migrants where no actual change of address had taken place. We have been advised of adjustments required to data by the Department of Health and these have been made to migration data.

The NHS Central Register (NHSCR) at Southport was computerised in early 1991, prior to which a three month time lag was assumed between a person moving and their re-registration with an NHS doctor being processed onto the NHSCR. Since computerisation, estimates of internal migration are based on the date of acceptance of the new patient by the HA (not previously available), and a one month time lag assumed.

It has been established that NHSCR data under-report the migration of males aged between 16 and 36 . Currently, however, there are no suitable sources of data available to enable adjustments or revisions to be made to the estimates. Further research is planned on this topic and new data sources may become available in the future. However, for the present time, historical estimates will not be revised and future estimates will not be adjusted.

\section{Marriages and divorces}

Marriages are tabulated according to date of

solemnisation. Divorces are tabulated according to date of decree absolute. The term 'divorces' includes decrees of nullity. The fact that a marriage or divorce has taken place in England, Wales, Scotland or Northern Ireland does not mean either of the parties is resident there.

\section{Civil Partnerships}

The Civil Partnership Act 2004 came into force on 5 December 2005 in the UK, the first day couples could give notice of their intention to form a civil partnership. The first day that couples could formally form a partnership was 19 December 2005 in Northern Ireland, 20 December 2005 in Scotland and 21 December 2005 in England and Wales.

(18 civil partnerships were formed under special arrangements before these dates. These are included in the figures for England and Wales).

Civil partnerships are tabulated according to date of formation and area of occurrence. The fact that a civil partnership has taken place in England, Wales, Scotland or Northern Ireland does not necessarily mean either of the parties is resident there.

\section{EU Enlargement}

The coverage of European countries in Table 1.1 has been updated to reflect the enlargement of the EU to 27 member countries (EU27). On 1 May 2004, 10 new member countries were added: Cyprus, Czech Republic, Estonia, Hungary, Latvia, Lithuania, Malta Poland, Slovakia and Slovenia. One 1 January 2007 a further 2 countries were added: Bulgaria and Romania.

\section{Sources}

Figures for Scotland and Northern Ireland have been provided by the General Register Office for Scotland and the Northern Ireland Statistics and Research Agency respectively. The International Passenger Survey (Tables 7.1-7.3) is conducted by the Surveys and Administrative Sources Directorate of ONS.

\section{Rounding}

All figures are rounded independently; constituent parts may not add to totals. Generally numbers and rates pe 1,000 population are rounded to one decimal place (e.g 123.4); where appropriate, for small figures (below 10.0), two decimal places are given (e.g 7.62). Figures which are provisional or estimated are given in less detail (e.g 123 or 7.6 respectively) if their reliability detail (e.g 123 or 7.6 respectively) if their reliability
does not justify giving the standard amount of detail. does not justify giving the standard amount of de
Where figures need to be treated with particular caution, an explanation is given as a footnote.

\section{Latest figures}

Figures for the latest quarters and years may be provisional and will be updated in future issues when later information becomes available. Where figures are not yet available, cells are left blank. 